ORIGINAL ARTICLE

\title{
Clinical, morphological, and molecular aspects of sialic acid storage disease manifesting in utero
}

\author{
R Froissart, D Cheillan, R Bouvier, S Tourret, V Bonnet, M Piraud, I Maire
}

J Med Genet 2005;42:829-836. doi: 10.1136/jmg.2004.029744

\begin{abstract}
See end of article for authors' affiliations

.....................

Correspondence to: Dr R Froissart, Centre d'Etude des Maladies Héréditaires du Métabolisme, Hôpital Debrousse, 29 rue Soeur Bouvier, 69322, Lyon, cedex 05 , France; roseline. froissart@chu-lyon.fr

Received 3 December 2004 Revised version received 15 March 2005 Accepted for publication 18 March 2005
\end{abstract}

\begin{abstract}
Background: Sialic acid storage diseases (SASDs) are caused by the defective transport of free sialic acid outside the lysosome. Apart from the Salla presentation in Finland, SASD is a very rare form of lysosomal storage disease (LSD) with approximately 35 cases, all diagnosed after birth, having been reported worldwide. We report a series of 12 French patients with very early manifestations, including eight fetuses diagnosed in utero.

Results: Ultrasound examination, fetal autopsy, or clinical examination showed prominent ascites, rarely progressing to complete hydrops, and highlighted the early severity of bone disease. Dramatic increase of free sialic acid in various biological samples confirmed the diagnosis in all cases. Storage staining affinities and storage distribution in placenta and fetal organs allowed differential diagnosis from other LSDs but cannot differentiate between SASD, sialidosis, and galactosialidosis. Fourteen different mutations were identified, showing the molecular heterogeneity of SASD in the French population. We found that the previously described p.Y306X mutation generated two different transcripts, and we identified seven novel mutations: three deletions (del exon 7, del exons10+11 and c.1296delT), one splice site mutation (c. 1350+1G $\rightarrow$ T) one nonsense mutation (p.W339X), and two missense mutations (p.R57C and p.G127E). Conclusions: The severity of our patients' genotypes is in agreement with their phenotypes but not with the importance and early appearance of the very frequent in utero manifestations. Minimal fetal disease in some patients and a reported case of heterogeneity of fetal involvement within a family suggest that factors other than the genotype influence fetal manifestations.
\end{abstract}

ysosomal free sialic acid storage diseases (SASDs; OMIM 269920]) are lysosomal transport disorders characterised -by the accumulation of free sialic acid within the lysosomes of most tissues and its increased excretion in urine. ${ }^{1}$ The SLC17A5 gene, responsible for lysosomal membrane sialic acid transport, ${ }^{2}$ is located in $6 q 14-15,{ }^{3}$ contains 11 exons, and encodes a 495 amino acid protein, sialin, predicted to have 12 transmembrane domains. The infantile form of SASD (ISSD) represents the most severe presentation (failure to thrive, severe psychomotor retardation, visceromegaly with ascites, and dysostosis multiplex) with onset at birth or in utero (fetal ascites/hydrops), and early death. The milder Salla disease is frequent in Finland: patients who are normal at birth develop psychomotor delay and ataxia during infancy. Intermediate forms have also been reported. However the number of "non-Salla" cases remains low, with about 35 having been reported in the literature, including 11 cases with in utero manifestations.

We report on the ultrasonographic, fetopathological, clinical, histochemical, biochemical, and molecular data of a series of 12 French cases from unrelated families with severe prenatal or perinatal SASD.

\section{MATERIALS AND METHODS \\ Patients}

Eight patients were diagnosed in utero and four after birth between 6 days and 2 months. An autopsy was performed for all except cases 1, 2, and 12. Informed consent was obtained from the parents for genetic studies, prenatal diagnoses, and autopsies.

In utero cases were diagnosed as part of a protocol set in our laboratory to diagnose LSDs among cases of non-immune hydrops fetalis or persistent ascites of unknown origin, after exclusion of other reasons such as chromosomal anomalies or infection with viruses, for example, parvovirus B19.

\section{Histochemical studies and biochemical diagnosis}

The biological materials sampled at autopsy were fixed in formalin, embedded in paraffin and stained with haematoxylin and eosin, and in some cases with periodic acid Schiff and Hale's acid colloidal iron.

Free sialic acid was detected by thin layer chromatography in biological fluids, and quantified as previously described. ${ }^{4}$

\section{DNA analysis}

Genomic DNA was extracted using the Flexigene DNA kit (Qiagen). The 11 exons and intron exon boundaries were amplified from genomic DNA (table 1). PCR was carried out in a total volume of $50 \mu \mathrm{l}$ containing $67 \mathrm{mmol} / \mathrm{l}$ Tris $\mathrm{HCl}$ $\mathrm{pH} 8.8,16 \mathrm{mmol} / \mathrm{l}(\mathrm{NH} 4)_{2} \mathrm{SO}_{4}, 0.01 \%$ Tween $20,2 \mathrm{mmol} / \mathrm{l}$ $\mathrm{MgCl}_{2}, 0.2 \mathrm{mmol} / \mathrm{l} \mathrm{dNTPs}, 0.4 \mu \mathrm{mol} / \mathrm{l}$ of each primer, $1 \mathrm{U}$ Taq polymerase (HotStar Taq; Qiagen) and $100 \mathrm{ng}$ of genomic DNA. Cycling conditions were: $95^{\circ} \mathrm{C}$ for 10 minutes, followed by 35 cycles of 30 seconds at $94^{\circ} \mathrm{C}, 30$ seconds (or 45 seconds for exons 1, 4, and the first PCR of exon 9) at annealing temperatures indicated in table 1,45 seconds at $72^{\circ} \mathrm{C}$, and a final extension at $72^{\circ} \mathrm{C}$ for 5 minutes. PCR products were sequenced using the DYEnamic ET Terminator Cycle Sequencing kit (Amersham Biosciences) and an ABI 373A fluorescent sequencer (Applied Biosystems).

\section{RNA analysis}

Total RNA was extracted from cultured fibroblasts (cases 3, 4, 7, 9, and 10), using the QIAamp RNA Blood Mini kit (Qiagen) and $\mathrm{l} \mu \mathrm{g}$ was reverse transcribed using the Amersham First Strand cDNA Synthesis kit (Amersham Biosciences). Total cDNA was amplified in three overlapping fragments (table 1 ): $95^{\circ} \mathrm{C}$ for 10 minutes, followed by 35

Abbreviations: GA, gestational age; LSD, lysosomal storage disease; SASD, sialic acid storage disease 
Table 1 Primers used for the amplification of the sialin gene (SLC17A5) and CDNA

\begin{tabular}{|c|c|c|c|c|}
\hline Fragment & Primers $\left(5^{\prime} \rightarrow 3^{\prime}\right)$ & $\begin{array}{l}\text { Nucleotide } \\
\text { position }\end{array}$ & $\begin{array}{l}\text { Size } \\
\text { (bp) }\end{array}$ & $\begin{array}{l}\mathrm{Ta} \\
\text { ( } \mathrm{C})\end{array}$ \\
\hline \multicolumn{5}{|c|}{ Genomic DNA } \\
\hline \multirow[t]{2}{*}{ Exon 1} & Forward: AGTCCAACCCAAGCCAGAGTT & $50-70$ & 462 & 54 \\
\hline & Reverse: AACGGGCTCCCCTCTTAATGT & $511-491$ & & \\
\hline \multirow[t]{2}{*}{ Exon 2} & Forward: AGGAGTTCAAGACCAGCCTAAGCAACATG & $9456-9484$ & 436 & 60 \\
\hline & Reverse: CCTGGGAAAACACAAAAAGAAAG & $9891-9869$ & & \\
\hline \multirow[t]{2}{*}{ Exon 3} & Forward: AATCTCATTTATATGTACTTACATGCCAGT & $12137-12166$ & 418 & 53 \\
\hline & Reverse: GGTTCATATTCATACCAAAGAATGACATC & $12554-12526$ & & \\
\hline \multirow[t]{2}{*}{ Exon 4} & Forward: CATGGAACCTGATTCGTTTGATTCTTATC & $15531-15559$ & 305 & 57 \\
\hline & Reverse: AACATTGCATCGTTCTGGTATGCAGGCC & $15835-15808$ & & \\
\hline \multirow[t]{2}{*}{ Exon 5} & Forward: CCCATCCTCTGTAAGCAGTAGACTTGTC & $17362-17389$ & 295 & 57 \\
\hline & Reverse: CAGGAAGTGTITCAGAACTGTGGTICAG & $17656-17629$ & & \\
\hline \multirow[t]{2}{*}{ Exon 6} & Forward: TCAAGACATGTAAAAATTGTTGTTGGTGC & $18543-18571$ & 343 & 53 \\
\hline & Reverse: CTACTITGTCTAGAGCATGCACAATAGG & $18885-18858$ & & \\
\hline \multirow[t]{2}{*}{ Exon 7} & Forward: CGGTACAGATCTAAGCATTAACATAGC & $32132-32158$ & 336 & 60 \\
\hline & Reverse: AGGACAGCAGAGTAAAATGGAAG & $32467-32445$ & & \\
\hline \multirow[t]{2}{*}{ Exon 8} & Forward: CCTTTGCTTTCAAGTGGTGGTC & $38610-38631$ & 400 & 63 \\
\hline & Reverse: TAGGCAGAAATCCCCACAAACA & $39009-38988$ & & \\
\hline \multirow[t]{5}{*}{ Exon 9} & First PCR: & & & \\
\hline & Forward: CCACATTCTGTGTCAGCTATTGCTTCTC & $43272-43299$ & 788 & 62 \\
\hline & $\begin{array}{l}\text { Reverse: CGATCTCAGCTCACTGCAACCTC } \\
\text { Second PCR. }\end{array}$ & $44059-44037$ & & \\
\hline & Forward: GTCTTCCAGGCAATATAGTGTTTCTACAG & $43480-43508$ & 389 & 65 \\
\hline & Reverse: AAGTGCTGGGATTACAGGTGTGAGTCACC & $43860-43832$ & & \\
\hline \multirow[t]{2}{*}{ Exon 10} & Forward: AGGCTGCAGTGAGCTGAGATCATCCCAC & $53563-53590$ & 397 & 63 \\
\hline & Reverse: ATACTTCCCATCCATTAAGGCATTTAGC & $53959-53931$ & & \\
\hline \multirow[t]{2}{*}{ Exon 11} & Forward: ATGTGGCTGITITAACACTCTIGTGACAC & $58844-58872$ & 334 & 63 \\
\hline & Reverse: ATAGAATGCTTACACAATACAGAAGGCAC & $59167-59138$ & & \\
\hline \multicolumn{5}{|l|}{ cDNA } \\
\hline 1 & $\begin{array}{l}\text { Forward: GCGCTCCCTTCTCTGCCA } \\
\text { Reverse: ACACCCTCTCCTAGTCCT }\end{array}$ & $\begin{array}{l}222-239 \\
800-783\end{array}$ & 579 & 57 \\
\hline \multirow[t]{2}{*}{2} & Forward: CAGCAAAATAGGGGGGAAAA & $660-679$ & 647 & 57 \\
\hline & Reverse: CAGACAGGATCATACATAAC & $1306-1287$ & & \\
\hline \multirow[t]{2}{*}{3} & Forward: CCTGCCACTTTGGGCTAT & $1134-1151$ & 697 & 57 \\
\hline & Reverse: TACAGAAGGCACTTTGAG & $1830-1813$ & & \\
\hline
\end{tabular}

cycles of 30 seconds at $94^{\circ} \mathrm{C}, 45$ seconds at $57^{\circ} \mathrm{C}, 45$ seconds at $72^{\circ} \mathrm{C}$, and a final extension at $72^{\circ} \mathrm{C}$ for 5 minutes, and were sequenced.

\section{Real time quantitative PCR}

Exon 7 (family 3) and exon 9 (family 7 and patient 9) were quantified using LC-Fast Start DNA Master SYBR Green and a Light Cycler apparatus (both Roche Diagnostics). The AGT (alanine glyoxylate aminotransferase) gene was amplified in separate experiments as reference internal control. Each sample was tested in triplicate. Thermocycling was done in a final volume of $10 \mu \mathrm{l}$ containing $4 \mathrm{mmol} / \mathrm{l} \mathrm{MgCl}_{2}, 0.4 \mu \mathrm{mol} / \mathrm{l}$ of each primer and $3 \mathrm{ng}$ DNA. Cycling conditions were: denaturation at $95^{\circ} \mathrm{C}$ for 8 minutes, and 40 cycles of 15 seconds at $95^{\circ} \mathrm{C}, 5$ seconds at $60^{\circ} \mathrm{C}$ (exon 7 ) or $57^{\circ} \mathrm{C}$ (exon 9 ), and 13 seconds (exon 7) or 6 seconds (exon 9) at $72^{\circ} \mathrm{C}$. A melting curve was obtained by increasing the temperature from $65^{\circ} \mathrm{C}$ to $95^{\circ} \mathrm{C}$ with a transition rate of $0.1^{\circ} \mathrm{C} / \mathrm{s}$. A standard curve was determined for target and reference genes and used to quantify the amount of DNA obtained using RelQant software (Roche Diagnostics).

\section{RESULTS}

\section{Clinical and ultrasound examinations}

The findings of the examinations are shown in table 2 .

\section{Neonatal cases}

Pregnancy ultrasound examination revealed minimal abnormalities (cases 1 and 2), while severe intrauterine growth retardation and prominent ascites were observed in cases 3 and 4, although no complete hydrops was observed.

Severe ascites was present at birth, requiring repeated extensive punctures in case 3 , but was absent in case 1 at
1.5 months of life. Splenomegaly was associated with hepatomegaly except in case 1. Inguinal hernias were found in cases 1 and 3, cardiomegaly in cases 1, 2, and 3, and moderate pericardic effusions in cases 2 and 4 . Facial dysmorphy included coarse facial features, flat bridge, anteverted nostrils, and micrognathy with median facial hypoplasia. Severe growth retardation, or hypotrophy was reported in all cases. Dysostosis included irregular metaphyses and diffused demineralisation (case 1), club feet, short femurs, fractures, abnormal cortices, enlarged metaphyses, and stippled calcaneum and epiphyses (case 2), hip dysplasia (case 3), stippled tarsal and sacral bones, hypoplasia and anterior beaking of the dorsal vertebrae (D5-D10), and hypoplasia of the distal phalanges (case 4). Case 3 had pale and sparse hairs with pale retinas. Hypotonia was reported in cases 1,3 , and 4 . Pachygyria was observed in case 3 at cerebral scan and confirmed at autopsy. Vacuolated lymphocytes, looked for in cases 1 and 2, were observed only in case 2 . Hypoalbuminaemia with pancytopenia was found in cases 2 and 4, and anaemia only in case 3 .

\section{Antenatal cases}

Ultrasound examination (fig 1 and Carbillon et $a l^{5}$ ) showed consistent prominent ascites between 16 to $28 \mathrm{GA}$, associated with oedema, leading in some cases to a complete hydrops fetalis. More occasional findings included ventriculomegaly (three cases), hepatomegaly (four), short femurs (two), generalised intrauterine growth retardation (one), or club feet (two). Increased nuchal thickness at $10 \mathrm{GA}$ was the first symptom in case 11 .

The diagnosis in these eight fetuses led to medical termination in six cases, and in utero fetal death occurred in cases 10 and 12 . 
Table 2 Ultrasonographic, clinical and autopsy findings in 12 cases of severe prenatal or perinatal SASD

\begin{tabular}{|c|c|c|c|c|c|c|c|c|c|c|}
\hline \multirow[b]{2}{*}{$\begin{array}{l}\text { Pt. } \\
\text { no. }\end{array}$} & \multirow{2}{*}{$\begin{array}{l}\text { Age at } \\
\text { death } \\
\text { or MT } \\
\text { (GA) }\end{array}$} & \multirow[b]{2}{*}{$\begin{array}{l}\text { Consang./ } \\
\text { recurrence }\end{array}$} & \multicolumn{2}{|c|}{ Ultrasound examination } & \multirow[b]{2}{*}{$\begin{array}{l}\text { Age at } \\
\text { birth (GA) }\end{array}$} & \multicolumn{5}{|c|}{ Examination at birth or at fetal autopsy } \\
\hline & & & GA & Abnormalities & & Ascites & Oedema & HM & $\begin{array}{l}\text { Facial } \\
\text { dysmorphy }\end{array}$ & Dysostosis \\
\hline \multicolumn{11}{|c|}{ Neonatal forms } \\
\hline 1 & $>2$ years ${ }^{*}$ & $+/ 2 \mathrm{SA}$ & 35 & $\begin{array}{l}\text { Prefrontal oedema } \\
\text { Transient ventriculomegaly }\end{array}$ & 35 & $\begin{array}{l}-\dagger \\
\text { (at } 1.5 \\
\text { months) }\end{array}$ & Prefrontal & + & + & + \\
\hline 2 & 2 months & $-1-$ & 34 & Short femur & 34.5 & + & $\begin{array}{l}\text { Inferior } \\
\text { limbs }\end{array}$ & + & + & + \\
\hline 3 & 5 months & $-1-$ & 16 & Ascites, IUGR & 28 & ++ & Feet & + & + & + \\
\hline 4 & 1.5 months & $-1-$ & 34 & $\begin{array}{l}\text { Ascites, pericardic effusion, } \\
\text { IUGR, oligoamnios }\end{array}$ & 35 & ++ & $\begin{array}{l}\text { Socket } \\
\text { and hand }\end{array}$ & + & + & + \\
\hline \multicolumn{11}{|c|}{ Antenatal forms } \\
\hline $5 \ddagger$ & $28 \mathrm{GA}$ & $+/-$ & 26.5 & $\begin{array}{l}\text { Ascites, HM, club feet, } \\
\text { IUGR, oligoamnios }\end{array}$ & & + & Testis & + & + & + \\
\hline 6 & $29 \mathrm{GA}$ & $-/-$ & 28 & $\begin{array}{l}\text { Prefrontal oedema, } \\
\text { peritoneal effusion, thick } \\
\text { placenta } \\
\text { Prefrontal and retrocervical } \\
\text { oedema, ascites, HM, } \\
\text { ventriculomegaly }\end{array}$ & & + & Cervical & + & + & + \\
\hline $7 \S$ & $26 \mathrm{GA}$ & $-/ 2 \mathrm{SA}$ & 19 & $\begin{array}{l}\text { Ascites, hydramnios, } \\
\text { dysmorphy, short limbs, } \\
\text { ventriculomegaly }\end{array}$ & & + & ? (Lysis) & ? (lysis) & + & + \\
\hline 8 & $24 \mathrm{GA}$ & $? /-$ & 20 & Ascites, short femur & & + & Hydrops & $\begin{array}{l}\text { Not weighted } \\
\text { (congestive) }\end{array}$ & + & - \\
\hline & & & 21 & $\begin{array}{l}\text { Hydrops, short femur, } \\
\text { ventriculomegaly }\end{array}$ & & & & & & \\
\hline 99 & $19 \mathrm{GA}$ & $-/+$ & 16 & $\begin{array}{l}\text { Ascites, hydrops, mild } \\
\text { nuchal thickness }\end{array}$ & & + & Hydrops & + & + & $?$ (no $x$ ray) \\
\hline 10 & $\begin{array}{l}34 \mathrm{GA} \\
\text { (IUFD) }\end{array}$ & $+/-$ & 28 & Ascites, hydrops, mild HM & & + & Hydrops & + & + & + \\
\hline 11 & $22 \mathrm{GA}$ & $-1-$ & $\begin{array}{l}10 \\
18\end{array}$ & $\begin{array}{l}\text { Nuchal thickness } \\
\text { Ascites, cephalic and } \\
\text { truncal oedema, pleural } \\
\text { effusion, club feet }\end{array}$ & & + & Hydrops & - & + & + \\
\hline 12 & $\begin{array}{l}30 \mathrm{GA} \\
\text { (IUFD) }\end{array}$ & $+/-$ & 22 & $\begin{array}{l}\text { Ascites, pleural and } \\
\text { pericardic effusion, } \\
\text { subcutaneous oedema }\end{array}$ & $\begin{array}{l}\text { No data } \\
\text { available }\end{array}$ & & & & & \\
\hline
\end{tabular}

Fetal autopsy confirmed the presence of ascites, described as jelly-like peritonitis in cases 5 and 10 (also reported after birth in case 4). Ascites was associated with oedema or complete hydrops (fig. 2). A placental hydrops was also found in the five cases (cases 6, 8, 9, 10, and 11) in which the placenta was weighed (of a total of six cases). Pleural effusions were found in cases 8 and 11 , a mild cardiomegaly in case 10, and a mild hepatomegaly in the four cases (of five) in which the liver could be weighed. Club feet were reported in cases 5, 7, and 11, and short limbs in cases 7 , 8,10 , and 11. Facial dysmorphia (fig 2) was consistent and as described after birth. Fetal $x$ rays were performed in cases $6,7,8,10$, and 11; no anomaly could be observed in case 8 , while stippled epiphyses at various locations (such as the inferior femur and ankle) were found in the other cases, together with bone transparency and irregular metaphyses in cases 6 and 7. Anaemia was reported in fetus 10, but was not commonly looked for in our cases.

In 8 of the identified families, 16 prenatal diagnoses were further performed on trophoblast biopsy, avoiding recurrence in 4 cases (table 3). A fetal autopsy was performed for three of these cases at 12-13 GA. The fetus of family 2 had no macroscopic nor bone $x$ ray abnormality and the fetus of family 7 had a mild dysostosis. The fetus of family 5 presented with a moderate dysmorphy, stippled epiphyses,
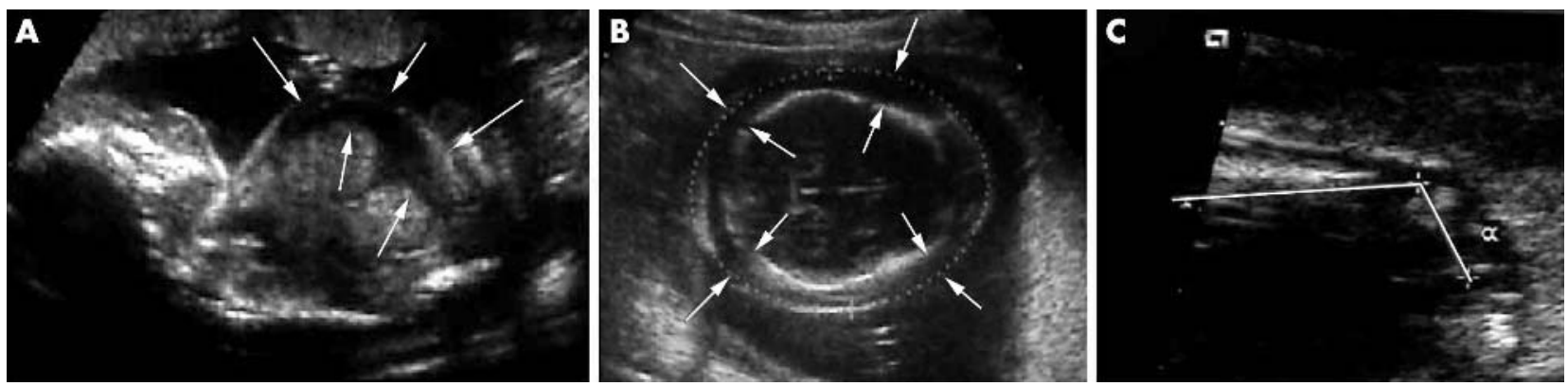

Figure 1 Ultrasound findings in SASD fetus; case 11 at 18 GA (courtesy of Dr J E Develay-Morice). (A) Fetal ascites; (B) pericephalic oedema; (C) club foot. 

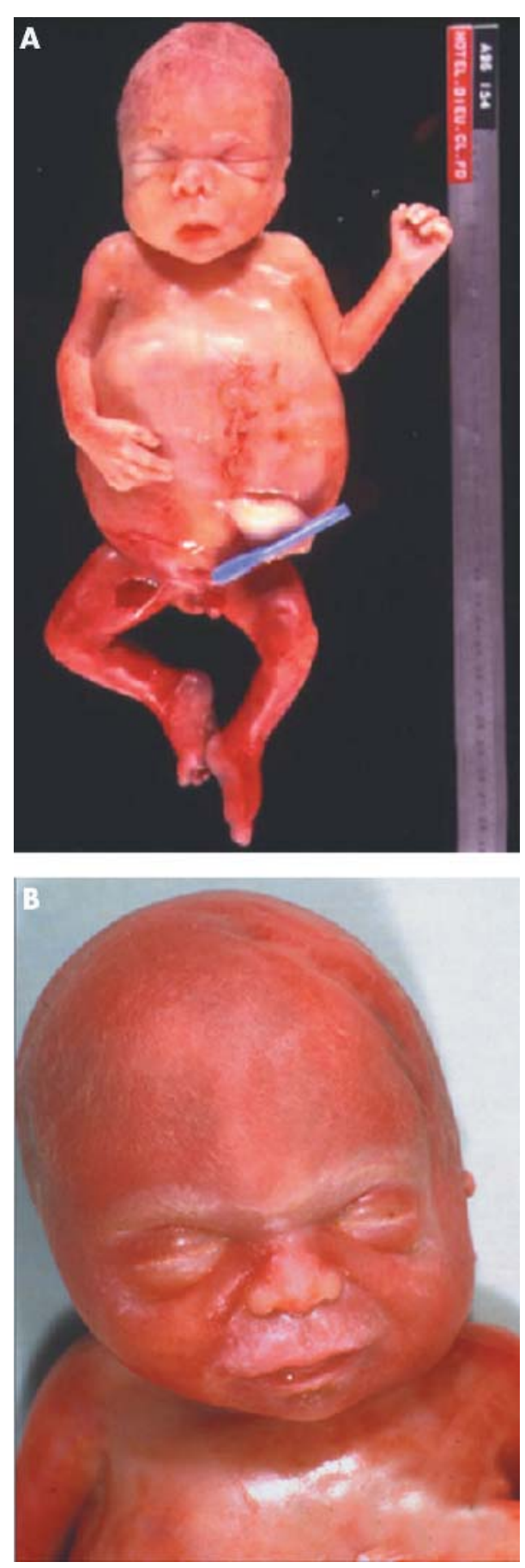

Figure 2 Morphological aspects in SASD fetuses. (A) Oedema and distention of abdomen due to ascites in case 8 at 24 GA (courtesy of Professor Dechelotte); (B) coarse facial features, hypertelorism, depressed nasal bridge, anteverted nostrils, long philtrum, brachycephaly, and prominent ocular globes in case 9 at 19 GA (courtesy of Professor M Catala).

and punctuated vertebral bodies, mild subcutaneous oedema, and severe ascites.

\section{Histochemical studies}

Histopathological examination of the placenta, performed in six cases, showed extensive vacuolisation of both syncytiotrophoblastic and Hofbauer cells (fig 3). Fetal storage present in most organs was better seen in podocytes and highlighted by colloidal iron staining.

\section{Free sialic acid measurement}

Free sialic acid was dramatically increased in urine (14-40 times mean normal value), amniotic cells (13-36 times) and fibroblasts (10-67 times) (table 3 ). The increase was only moderate in amniotic fluid supernatant (2.6-7.9 times), but some overlap occured with the controls as for the ratio of free to total sialic acid.

In the four affected fetuses diagnosed in further pregnancies, the free sialic acid content (9-21 times normal value) and the ratio of free to total sialic acid were always dramatically increased in trophoblasts.

\section{DNA and cDNA analysis}

Fourteen different gene alterations, including seven novel, were identified (table 4): four small deletions (c.527delG, c.533delC, c.1138delGT, and c.1296delT) leading to a frameshift and a premature stop codon; one small deletion (p.SSLRN268-272del) leading to the deletion of five aminoacids (SSLRN); three large deletions (del exon 7, del $\geqslant$ exon 9, del exons 10 and 11), two splice site mutations $($ c. $1259+1 \mathrm{G} \rightarrow \mathrm{A}, \mathrm{c.1350+1G \rightarrow T})$, two nonsense mutations (p.Y306X, p.W339X), and two missense mutations (p.R57C, p.G127E). Only three alterations (p.SSLRN268-272del, p.Y306X, and p.W339X) were found in more than one patient.

In family 3, the patient was homozygous for the c. $1259+1 \mathrm{G} \rightarrow$ A mutation, and cDNA study showed only one transcript of abnormal size, lacking exon 9. The father was heterozygous, but the mother was not. Quantitative PCR of exon 9 of the patient's and mother's genomic DNAs confirmed that they were heterozygous for a deletion including at least the complete exon 9. The deletion does not encompass the entire gene as the patient is heterozygous for the p.S202S polymorphism in exon 4 (dbSNP rs3757112).

In family 7, sequencing of patient's genomic DNA allowed identification only of the mutation p.R57C at the heterozygous state. The study of patient's cDNA showed two transcripts of different sizes: one of normal size containing the mutation and a shorter one lacking exon 7. The mother was heterozygous for the p.R57C mutation. Quantitative PCR of exon 7 from the patient's and father's genomic DNA confirmed that they were heterozygous for a deletion including the complete exon 7.

In patient 9, the study of genomic DNA showed that he was homozygous for the p.Y306X mutation. Study of cDNA showed two transcripts of different sizes: a normal size cDNA carrying the p.Y306X mutation and a shorter cDNA lacking the complete exon 7. Quantitative PCR of exon 7 showed that two alleles were present in patient's DNA.

In patient 10, exons 10 and 11 could not be amplified from genomic DNA although the deletion could extend beyond these two exons.

\section{DISCUSSION}

Our experience shows that SASD frequency is probably underestimated because the most common form is lethal in utero, as with mucopolysaccharidosis type VII. ${ }^{6}$

\section{Clinical data}

In contrast to our series (table 2), all the cases in the literature were diagnosed after birth, although the presence of antenatal signs was documented in 11 cases..$^{7-16}$

The earliest ultrasonographic sign was increased nuchal thickness at 10 GA preceding a more complete picture (case 11). The most prominent sign consisted of ascites discovered between $13^{11}$ and $32 \mathrm{GA}^{13}$ which could require repeated punctures in utero (our case 8 and case 2 of Lemyre et al ${ }^{12}$ ) or at birth (case 4). Antenatal ascites was absent in two of our four neonatal cases (although it was present at birth in case 


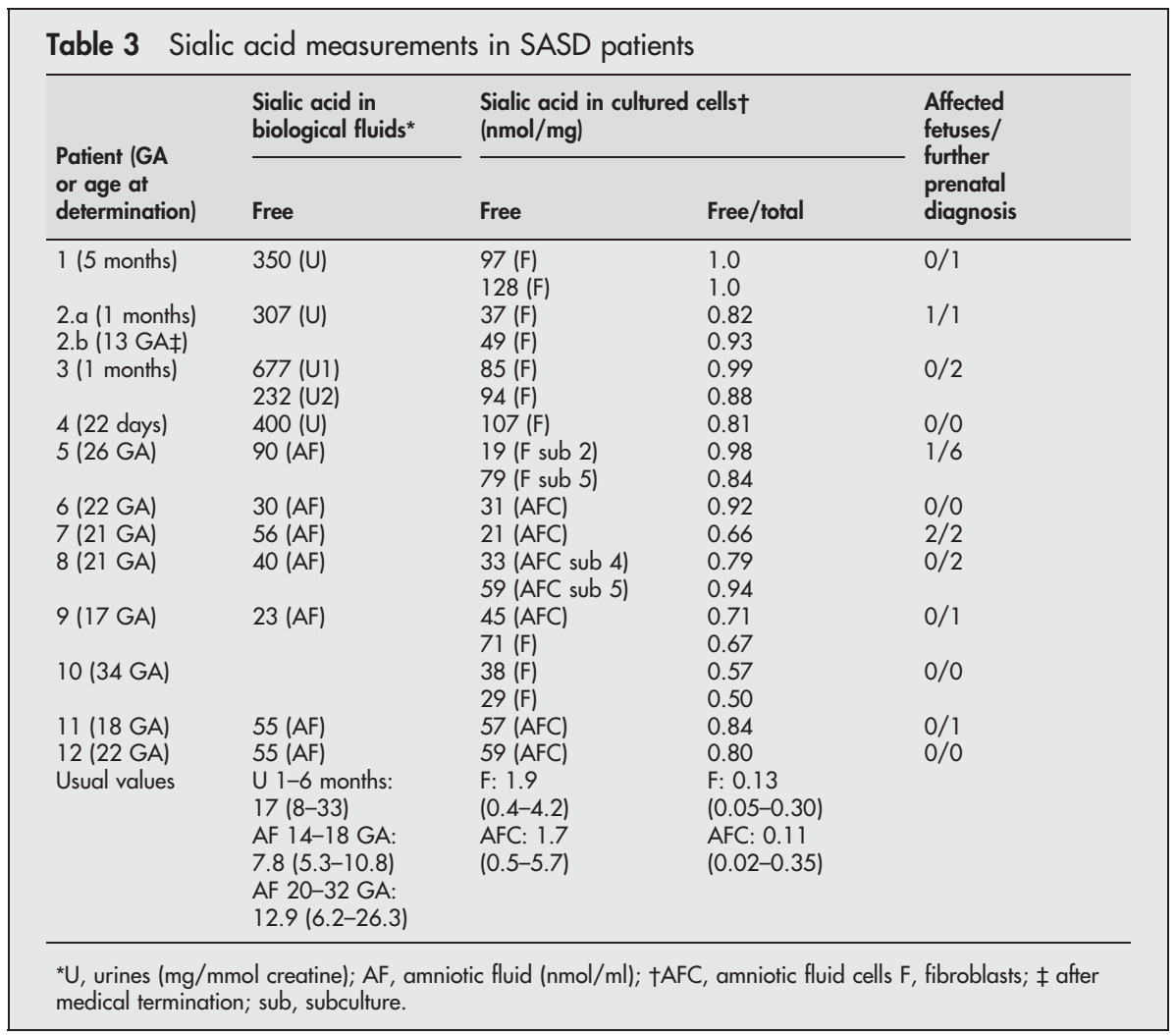

2 ), in two further affected fetuses in families 2 and 7 at 12$13 \mathrm{GA}$, and in one case in the literature, ${ }^{14}$ and was only transient in case 3 of Lemyre et al. ${ }^{12}$ In some cases, complete fetal hydrops was described, although it was never as severe as in our 21 cases of antenatal mucopolysaccharidosis VII (personal unpublished data) and never led to severe pulmonary hypoplasia. Fetal anaemia (reported in case 10 and in one case in the literature requiring fetal transfusion ${ }^{10}$ ) and hypoalbuminaemia (reported in about half of the cases: our cases 3 and 4, Pueschel et al, ${ }^{8}$ Utagawa et al ${ }^{13}$ case 2 of Lemyre et $a l^{12}$ and Kirschner et $a l^{14}$ ) may contribute to the severity of ascites or hydrops. ${ }^{17}$ Hepatomegaly was seen at ultrasound examination only in a few cases, although observed more frequently at autopsy (table 2). It may be mild or absent at birth in neonatal cases and increases with time of survival. Liver involvement could also explain the ascites. In addition, the conditions of fetal life may constitute a risk factor, as ascites tend to resolve after the perinatal period, according to our experience of LSDs. However, the mechanisms of in utero ascites remain poorly understood. Cardiomegaly, dysmorphy, and dysostosis also become more dramatic with time. Our series highlights the unexpected early severity of bone pathology in this disease. Presence of irregular metaphyses, diffuse osteopenia, and neonatal rickets, together with hypotrophy at birth, hypertrophic gums, and inguinal or umbilical hernias, led us to suspect a mucolipidosis type II in several cases. Interestingly, pigmentation defects (pale and sparse hairs, pale retina or albinoid fundi) and kidney involvement ${ }^{813} 15$ were reported in several cases as in sialidosis. ${ }^{18}$ If children survive long enough,
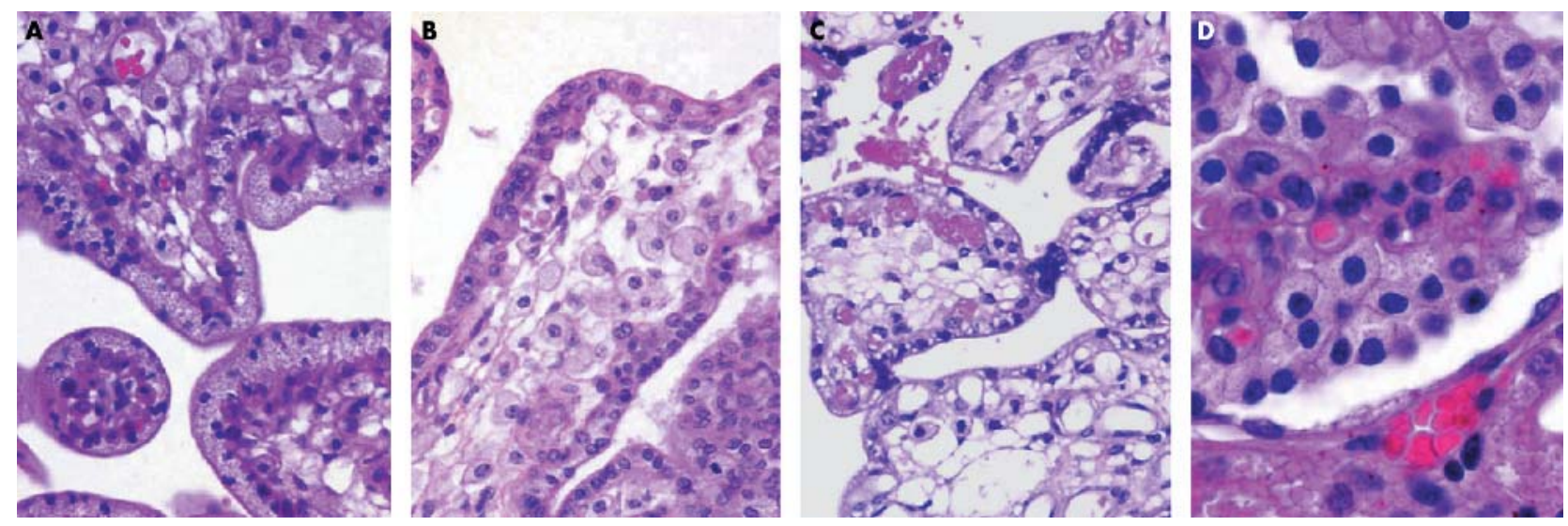

Figure 3 Microscopic findings in placenta of fetal LSD and in SASD fetus. (A) Placenta in SASD showing microvacuolation of both trophoblastic and Hofbaver cells. The cytoplasm appears microgranular rather than foamy. (B) Placenta in MPS VII showing storage only in Hofbaver cell. (C) Placenta in GM1 gangliosidosis showing storage in both trophoblastic and Hofbauer cells. Cytoplasmic vacuoles are larger than in SASD and MPS VII. (D) Renal podocytes in SASD with enlarged, clear and microgranular cytoplasm. Haematoxylin and eosin (A-C) $\times 240 ;(D) \times 600)$. 


\begin{tabular}{|c|c|c|c|c|c|c|}
\hline Patient & Allele & Mutation & $\begin{array}{l}\text { Nucleotide } \\
\text { change }\end{array}$ & $\begin{array}{l}\text { Position } \\
\text { (cDNA)* }\end{array}$ & Exon & $\begin{array}{l}\text { Parental } \\
\text { origin }\end{array}$ \\
\hline \multirow[t]{2}{*}{1} & 1 & p.W339X & $\mathrm{G} \rightarrow \mathrm{A}$ & 1016 & 8 & ND \\
\hline & 2 & p.W339X & $\mathrm{G} \rightarrow \mathrm{A}$ & 1016 & 8 & ND \\
\hline \multirow[t]{2}{*}{2} & 1 & c.533delC & delc & 533 & 4 & Mother \\
\hline & 2 & p.SSLRN268-272del & del $15 \mathrm{bp}$ & $802-816$ & 6 & Father \\
\hline \multirow[t]{2}{*}{$\begin{array}{l}3 \\
\text { Father }\end{array}$} & 1 & c. $1259+1 \mathrm{G} \rightarrow \mathrm{A}$ & $\mathrm{G} \rightarrow \mathrm{A}$ & $1259+1$ & intron 9 & \\
\hline & 2 & del $\geqslant \operatorname{exon} 9$ & & & & Mother \\
\hline \multirow[t]{2}{*}{$4 \dagger$} & 1 & c.527delG & delG & 527 & 4 & ND \\
\hline & 2 & p.Y306X & $T \rightarrow G$ & 918 & 7 & ND \\
\hline \multirow{2}{*}{$\begin{array}{l}5 \\
\text { Father }\end{array}$} & 1 & c. $1350+1 G \rightarrow T$ & $\mathrm{G} \rightarrow \mathrm{T}$ & $1350+1$ & intron 10 & \\
\hline & 2 & c. $1350+1 G \rightarrow T$ & $G \rightarrow T$ & $1350+1$ & intron 10 & \\
\hline \multicolumn{7}{|c|}{ c. $1350+I G \rightarrow I$} \\
\hline \multirow[t]{2}{*}{6} & 1 & p.G127E & $\mathrm{G} \rightarrow \mathrm{A}$ & 380 & 2 & ND \\
\hline & 2 & p.SSLRN268-272del & del $15 \mathrm{bp}$ & $802-816$ & 6 & ND \\
\hline 7 & $\begin{array}{l}1 \\
2\end{array}$ & $\begin{array}{l}\text { p.R57C } \\
\text { del exon } 7\end{array}$ & $\mathrm{C} \rightarrow \mathrm{T}$ & 169 & 2 & $\begin{array}{l}\text { Mother } \\
\text { Father }\end{array}$ \\
\hline \multirow[t]{2}{*}{8} & 1 & c.1138delGT & delGT & 1138 & 9 & Father \\
\hline & 2 & c.1138delGT & delGT & 1138 & 9 & Mother \\
\hline \multirow[t]{2}{*}{9} & 1 & p.Y306X & $T \rightarrow G$ & 918 & 7 & ND \\
\hline & 2 & p.Y306X & $T \rightarrow G$ & 918 & 7 & ND \\
\hline \multirow[t]{2}{*}{10} & 1 & del ex $10-11$ & & & & ND \\
\hline & 2 & del ex $10-11$ & & & & ND \\
\hline \multirow[t]{2}{*}{11} & 1 & p.Y306X & $T \rightarrow G$ & 918 & 7 & Father \\
\hline & 2 & c. 1296 delT & delT & 1296 & 10 & Mother \\
\hline \multirow[t]{2}{*}{12} & 1 & p.W339X & $\mathrm{G} \rightarrow \mathrm{A}$ & 1016 & 8 & ND \\
\hline & 2 & p.W339X & $\mathrm{G} \rightarrow \mathrm{A}$ & 1016 & 8 & ND \\
\hline
\end{tabular}

psychomotor retardation is severe, and seizures may appear. Outcome was always poor, with survival ranging from 2 days to 3 years.

\section{Microscopic examination}

In the placenta, vacuolisation of both Hofbauer and trophoblastic cells confirms the diagnosis of LSD and excludes Gaucher's disease (no placental storage), but does not allow discrimination between SASD, sialidosis, and galactosialidosis. ${ }^{19}$ In GMl gangliosidosis, the storage affects also both Hofbauer and trophoblastic cells, but vacuoles are usually larger and Hale staining differentiates these conditions. In mucolipidosis type II, Hofbauer cell storage is less prominent than trophoblastic cell storage. In mucopolysaccharidosis type VII, Hofbauer cell storage is present and trophoblastic cell storage is inconsistent and always less diffuse and extensive than in SASD, if present $150 \%$ of the cases in our experience).

In fetal organs, the storage cells, except Gaucher cells, are not characteristic. However, the different involvement of various organs and affected cell types and the different staining affinities of the storage facilitates the differential diagnosis. Positive Hale staining of the storage cells excludes GMl gangliosidosis. In mucoplysaccharidosis type VII, endothelial cell storage is prominent while epithelial cells are less affected. Demonstration of prominent kidney podocyte storage, stained by colloidal iron, does not allow discrimination of storage diseases involving sialic acid metabolism, or mucolipidosis type 2 .

\section{Biochemical diagnosis}

Biochemical diagnosis has been reported to be difficult in amniotic fluid supernatant, especially in Salla disease, ${ }^{1}$ and free sialic acid increase may be moderate even in cases with severe in utero presentation. Our experience confirms that prenatal diagnosis is reliable using measurement of free sialic acid in trophoblastic biopsies, avoiding the variability of free sialic acid concentration due to different subcultures (cases 5 and 8, table 3) and/or culture conditions. ${ }^{20}$ New technologies such as HPLC electrospray tandem mass spectrometry ${ }^{21}$ could facilitate the biochemical diagnosis.

\section{Molecular heterogeneity and genotype phenotype correlations}

A maximum number of 20 different alleles could be expected in our 12 cases, if we take into account the four families with known consanguinity (table 4). In fact, 14 different alleles including 7 novel were identified. This extreme heterogeneity contrasts with the general homogeneity of Salla disease in the Finnish population, in which the p.R39C mutation accounts for more than $95 \%$ of the alleles ${ }^{1}$ owing to a founder effect. ${ }^{22}$ French patients usually present with a very severe phenotype; only one Salla patient has been diagnosed during the past 25 years in our laboratory. ${ }^{23}$ The severity of SASD in our population and the fact that Salla presentation has been considered for years as the prototype of SASD, are probably responsible for underdiagnosis of this very rare condition.

The p.Y306X mutation has been previously reported in our patient 4 by another group, ${ }^{22}$ who could not find it in the transcript. We found this mutation in three patients, including one homozygote, and showed that this mutation in exon 7 was responsible for the generation of the expected mutated transcript and of a transcript missing exon 7, probably due to activation of a cryptic splice site.

All the identified mutations (table 4) apart from three were obviously severe, in accordance with the severe clinical presentation. The other three mutations include two novel missense mutations (p.R57C and p.G127E) and one small in frame deletion (p.SSLRN268-272del), leading to the deletion of five amino acids in a cytosolic loop of the sialin between transmembrane domains 6 and 7. ${ }^{2}$ Expression study of this latter mutation showed that a significant part of the mutated polypeptide could reach the Golgi apparatus where it was entirely retained, suggesting an inactivity of this mutant. ${ }^{24}$ The presence of the p.SSLRN268-272del mutation together 
with the p.R39C Salla mutation, which retains some function, ${ }^{24}$ in two reported patients ${ }^{25}{ }^{26}$ worsened the Salla phenotype. This p.SSLRN268-272del mutation was also found in our patient 2 in combination with the severe mutation c.533delC as in another patient in the literature; ${ }^{27}$ both presented a very close phenotype with few or no in utero manifestations and severe ISSD, although the course of the disease was more rapid in our patient, suggesting that other factors influence the course of the disease. The p.SSLRN268272del mutation was also found in our severe patient 6 in combination with the novel p.G127E mutation, leading to a drastic change of a highly conserved amino acid at the limit of the second transmembrane domain and the second cytosolic loop of the sialin. Our patient's phenotype confirms the severity of this missense mutation. The second novel missense p.R57C mutation also leads to a dramatic change in a highly conserved amino acid in the first transmembrane domain of the sialin and was associated with a large deletion in our severe patient 7 .

Although only severe genotypes were found in our 12 patients, in accordance with their severe phenotype, two (patients 1 and 2) did not have a severe in utero presentation. Patient 1, who was homozygous for the p.W339X mutation, had minimal in utero signs, in contrast with patient 12 with the same genotype. Patient 2, with the c.533delC/ p.SSLRN268-272del genotype had minimal in utero abnormalities, whereas patient 6, with the p.G127E/p.SSLRN268272 del genotype, had severe in utero presentation. These data suggest that other factors influence the severity and precocity of in utero phenotype. Additional arguments are brought by the reported clinical heterogeneity within a family. ${ }^{16}$ Similar in utero clinical heterogeneity within a family has also been reported in mucopolysaccharidosis IVA $^{28}$ and was also observed in Niemann-Pick type C (Dr M T Vanier; personal communication) suggesting that LSDs can be considered as a "risk factor" for development of fetal ascites and/or hydrops in the environmental conditions of in utero life. Furthermore, the defective sialic acid metabolism that plays a crucial role during fetal life may explain the severity of fetal manifestations in SASD, sialidosis, and galactosialidosis, which represent $43 \%$ ( $17 \%$ for the SASD) of the 70 cases we have diagnosed of lysosomal diseases manifesting in utero. This hypothesis is supported by the high frequency of in utero manifestations seen in 12 of 13, 7 of 12, and 8 of 9 families, respectively, diagnosed in our laboratory with these disorders.

\section{ACKNOWLEDGEMENTS}

we are indebted to all the clinicians and pathologists for making all their data available. Without their active collaboration, this paper could not have been written. Gynaecologists: Dr F Champion (CHU Lyon), Dr L Cordovi (Neuilly Plaisance), Professor P Gaucherand (CHU Lyon), Dr M Hoffet (CH Nîmes), Dr G Lefebvre (CHU Paris), Professor D Lemery (CHU Clermont-Ferrand), Professor P Poulain (CHU Rennes), Dr P Vaast (CHU Lille). Ultrasonographists: Dr J B Choukroun (CH U Paris), Dr J E Develay Morice (CH Nîmes), Dr A Guillot (Bourgoin Jallieu), Dr P Morcel (CHU Lyon). Geneticists: Dr Amram (CH Nîmes), Dr J Attia Sobol (CHU Lyon), Dr C Biggi (CHU Montpellier), Dr V Cormier-Daire (CHU Paris), Dr E Flori (CHU Strasbourg), Dr C Francannet (CHU Clermont Ferrand), Dr D Heron (CHU Paris), Professor B Le Marec (CHU Rennes), Professor B de Martinville (CHU Lille), Professor S Odent (CHU Rennes), Dr M O Peter (CH Mulhouse), Dr J Roume (CHI Poissy), Dr A Toutain (CHU Tours). Pathologists: Dr F Allias (CHU Lyon), Dr A M Beaufrère (CHU Clermont Ferrand), Dr M Bucourt (CHU Paris), Dr D Carles (CHU Bordeaux), Professor M Catala (CHU Paris), Professor P Dechelotte (CHU Clermont Ferrand), Dr B Gasser (CH Mulhouse), Dr M C Grangeponte (CHU Tours), Dr Y Hillion (CHI Poissy), Dr H Jouan (CHU Rennes), Dr B Le Bail (CHU Bordeaux), Dr L Loeuillet (CHU Rennes), Dr C Rouleau (CHU Montpellier). Paediatricians: Dr G Baujat (CHU Paris), Dr MH Blont (CHU Tours), Dr C Delfau (CHU Bordeaux), Professor J Geisert (CHU Strasbourg), Dr C Rondeau
(CHU Tours), Professor B Sandler (CHU Bordeaux), Dr A L Suc (CHU Tours), and Dr P Wipff (CH Mantes la Jolie). We also thank Dr MT Zabot and Mrs G Mandon (Hôpital Debrousse, Lyon) for performing all the cell cultures required in this study. We thank M Combier, $\mathrm{K}$ Jerez and C Guillon for their technical assistance. This study was supported by grants from VML (Vaincre les Maladies Lysosomales) and AFM/INSERM.

\section{Authors' affiliations}

R Froissart, D Cheillan, S Tourret, V Bonnet, M Piraud, I Maire, Centre d'Etude des Maladies Héréditaires du Métabolisme, Hôpital Debrousse, Lyon, France

R Bouvier, Laboratoire d'Anatomie Pathologique, Hôpital Edouard Herriot, Lyon, France

Competing interest: none declared

\section{REFERENCES}

1 Aula P, Gahl WA. Disorders of free sialic acid storage. In: Scriver CR, Beaudet AL, Sly WS, Valle D, eds. The metabolic and molecular bases of inherited disease. New York: Mc Graw Hill, 2001:5109-20.

2 Verheijen FW, Verbeek E, Aula N, Beerens CE, Havelaar AC, Joosse M, Peltonen L, Aula P, Galjaard H, van der Spek PJ, Mancini GM. A new gene, encoding an anion transporter, is mutated in sialic acid storage diseases. Nature Genet 1999;23:462-5.

3 Schleutker J, Leppanen P, Mansson JE, Erikson A, Weissenbach J, Peltonen L, Aula P. Lysosomal free sialic acid storage disorders with different phenotypic presentations - infantile form sialic acid storage disease and Salla disease represent allelic disorders on 6q14-15. Am J Hum Genet 1995;57:893-901.

4 Piraud M, Froissart R, Mandon G, Bernard A, Maire I. Amniotic fluid for screening of LSDs presenting in utero (mainly as non-immune hydrops fetalis). Clin Chim Acta 1996;248:143-55.

5 Carbillon L, Largilliere C, Bucourt M, Scheuer-Niro B, Levaillant JM, Uzan M. Ultrasound assessment in a case of sialic acid storage disease. Ultrasound Obstet Gynecol 2001;18:272-4.

6 Vervoort R, Islam MR, Sly WS, Zabot MT, Kleijer WJ, Chabas A, Fensom A, Young EP, Liebaers I, Lissens W. Molecular analysis of patients with betaglucuronidase deficiency presenting as hydrops fetalis or as early mucopolysaccharidosis VII. Am J Hum Genet 1996:58:457-71.

7 Daneman A, Stringer D, Reilly BJ. Neonatal ascites due to LSD. Radiology 1983;149:463-7

8 Pueschel SM, O'Shea PA, Alroy J, Ambler MW, Dangond F, Daniel PF, Kolodny EH. Infantile sialic acid storage disease associated with renal disease. Pediatr Neurol 1988;4:207-12.

9 Berra B, Gornati R, Rapelli S, Gatti R, Mancini GM, Ciana G, Bembi B. Infantile sialic acid storage disease: biochemical studies. Am J Med Genet 1995; 58:24-31.

10 Hale LP, van de Ven CJ, Wenger DA, Bradford WD, Kahler SG. Infantile sialic acid storage disease: a rare cause of cytoplasmic vacuolation in pediatric patients. Pediatr Pathol Lab Med 1995; 15:443-53.

11 Sewell AC, Poets CF, Degen I, Stoss H, Pontz BF. The spectrum of free neuraminic acid storage disease in childhood: clinical, morphological and biochemical observations in three non-finnish patients. Am J Med Genet 1996;63:203-8.

12 Lemyre E, Russo P, Melancon SB, Gagne R, Potier M, Lambert M. Clinical spectrum of infantile free sialic acid storage disease. Am J Med Genet 1999;82:385-91.

13 Utagawa CY, Sugayama SM, Ribeiro EM, Bertola DR, Baba ER, Burin MG, Lewis E, Coelho HC, Fensom AH, Marques-Dias MJ, Gonzales CH, Kim CA Giugliani R Infantile sialic acid storage disease: report of the first case in South America. Clin Genet 1999;55:386-7.

14 Kirchner L, Kircher S, Salzer-Muhar U, Paschke E, Birnbacher R, StocklerIpsiroglu S. Infantile sialic acid storage disease and protein-losing gastroenteropathy. Pediatr Neurol 2003;28:313-17.

15 Parazzini C, Arena S, Marchetti L, Menni F, Filocamo M, Verheijen FW, Mancini GM, Triulzi F, Parini R. Infantile sialic acid storage disease: serial ultrasound and magnetic resonance imaging features. Am J Neuroradiol 2003;24:398-400.

16 Landau D, Cohen D, Shalev H, Pinsk V, Yerushalmi B, Zeigler M, Birk OS. A novel mutation in the SLC17A5 gene causing both severe and mild phenotypes of free sialic acid storage disease in one inbred Bedouin kindred. Mol Genet Metab 2004;82:167-72.

17 Machin GA. Hydrops revisited: literature review of 1414 cases published in the 1980s. Am J Med Genet 1999;34:366-90.

18 Thomas GH. Disorders of glycoprotein degradation: alpha-mannosidosis beta- mannosidosis, fucosidosis and sialidosis. In: Scriver CR, Beaudet AL, Sly WS, Valle D, eds. The metabolic and molecular bases of inherited disease. New York: McGraw Hill, 2001:3507-33.

19 Bouvier R, Maire I. Diagnostic des maladies de surcharge lysosomale à révélation foetale. Ann Pathol 1997;17:277-80

20 Salomaki P, Aula N, Juvonen V, Renlund M, Aula P. Prenatal detection of free sialic acid storage disease: genetic and biochemical studies in nine families. Prenat Diagn 2001;21:354-8.

21 Valianpour F, Abeling NG, Duran M, Huijmans JG, Kulik W Quantification of free sialic acid in urine by HPLC-electrospray tandem mass spectrometry: a 
tool for the diagnosis of sialic acid storage disease. Clin Chem 2004;50:403-9.

22 Aula N, Salomaki P, Timonen R, Verheijen F, Mancini G, Mansson JE, Aula P, Peltonen $\mathrm{L}$. The spectrum of SLC17A5-gene mutations resulting in free sialic acid storage diseases indicates some genotype-phenotype correlation. Am J Hum Genet 2000;67:832-40.

23 Echenne B, Vidal M, Maire I, Michalski JC, Baldet P, Astruc J. Salla disease in one non-Finnish patient. Eur J Pediatr 1986;145:320-2.

24 Aula N, Jalanko A, Aula P, Peltonen L. Unraveling the molecular pathogenesis of free sialic acid storage disorders: altered targeting of mutant sialin. Mol Genet Metab 2002;77:99-107.

25 Biancheri R, Verbeek E, Rossi A, Gaggero R, Roccatagliata L, Gatti R, van Diggelen O, Verheijen FW, Mancini GM. An Italian severe Salla disease variant associated with a SLC17A5 mutation earlier described in infantile sialic acid storage disease. Clin Genet 2002;61:443-7.
26 Kleta R, Aughton DJ, Rivkin MJ, Huizing M, Strovel E, Anikster Y, Orvisky E, Natowicz M, Krasnewich D, Gahl WA. Biochemical and molecular analyses of infantile free sialic acid storage disease in North American children. Am J Med Genet 2003;120a:28-33.

27 Tylki-Szymanska A, Czartoryska B, Lugowska A, Verheijen FW, Mancini GM, Rokicki D, Taybert J, Chmielinska E. Infantile sialic acid storage disease (ISSD): Report of the first case detected in Poland. Ped Int 2003;5:199-200. 28 Beck M, Braun S, Coerdt W, Merz E, Young E, Sewell AC. Fetal presentation of Morquio disease type A. Prenat Diagn 1992:12:1019-29.

29 Poulain P, Odent S, Maire I, Milon J, Proudhon JF, Jouan H, Le Marec B. Fetal ascites and oligohydramnios: prenatal diagnosis of a sialic acid storage disease (index case). Prenat Diagn 1995; 15:864-7.

30 Lefebvre G, Wehbe G, Heron D, Vautjoer Brouzes D, Choukroun JB, Darbois $Y$. Recurrent nonimmune hydrops fetalis: a rare presentation of sialic acid storage disease. Genet Couns 1999;10:277-84. 